\title{
Evaluation of ZP2 domains of functional importance with antisera against synthetic ZP2 peptides
}

\author{
E. Hinsch ${ }^{1}$, W. Hägele ${ }^{1}$, R-M. Bohle ${ }^{2}$, W-B. Schill ${ }^{1}$ and K-D. Hinsch ${ }^{1}$ \\ ${ }^{\prime}$ Centre of Dermatology and Andrology, Justus-Liebig-University, Giessen, Gaffkystr. 14, 35385 Giessen, Germany; and \\ ${ }^{2}$ Centre of Pathology, Justus-Liebig-University Giessen, Langhansstr. 10, 35385 Giessen, Germany
}

\begin{abstract}
The mouse zona pellucida protein ZP2 plays an important role in the process of fertilization by mediating secondary sperm binding to mammalian oocytes. ZP2 primary structures are highly conserved as revealed by cDNA cloning. The aim of the study was to identify ZP2 domains of functional relevance. Antisera were raised against synthetic peptides that are either conserved in the structure of ZP2 from different mammalian species (AS ZP2-20) or present in the human ZP2 but not in the mouse ZP2 amino acid sequence (AS ZP2-26). Antibody binding to zona pellucida proteins was assessed by assaying the antisera with human hemizonae. Using human zonae pellucidae, we demonstrated that anti-ZP2 common antibodies and anti-ZP2 human peptide antibodies react with human zona pellucida antigens. For the first time, ZP2 domains of functional relevance for human sperm-oocyte interaction could be identified applying the competitive hemizona assay. Antiserum AS ZP2-20 significantly inhibited binding of spermatozoa to test hemizonae, whereas treatment of hemizonae with AS ZP2-26 did not influence sperm-oocyte interaction. These results show that antibodies against synthetic $Z \mathrm{P} 2$ peptides react with $\mathrm{ZP} 2$ protein and that $A S$ ZP2-20 identifies a linear ZP2 epitope that is of possible functional importance for sperm-oocyte interaction.
\end{abstract}

\section{Introduction}

Gamete recognition and specific sperm binding to the oocyte occur through complementary molecules and are obligatory processes for successful fertilization (Yanagimachi, 1994). The mammalian oocyte is protected by the zona pellucida, an acellular coat surrounding the plasma membrane of the oocyte. The zona pellucida consists of different glycoproteins, depending on the species. One or more of the zona pellucida proteins are responsible for sperm binding and the subsequent induction of the acrosome reaction (Wassarman, 1990). Polypeptides similar to mouse ZP1 (ZPB), ZP2 (ZPA) and $Z P 3$ (ZPC) proteins that are present as polypeptides with different apparent molecular masses on SDS-PAGE have been defined in various mammals (Liang and Dean, 1993; Harris $e t$ al., 1994). The human zona pellucida also consists of three glycoproteins, named ZP1 (90-110 kDa), ZP2 (64-78 kDa) and ZP3 (57-73 kDa) (Shabanowitz and O'Rand and, 1988).

As has been shown in the mouse, ZP1 is the homodimeric filament crosslinker held together by intermolecular disulphides (Greve and Wassarman, 1985). The murine ZP3 protein is responsible for species-specific binding of spermatozoa to the oocyte and for the induction of the acrosome reaction (Vazquez et al., 1989).
After ZP3-mediated acrosomal exocytosis, the spermatozoon is postulated to bind to ZP2 (Bleil et al., 1988). This interaction is required for the second step of sperm-zona pellucida interaction by maintaining the association of the spermatozoon with the zona as it progresses through the oocyte glycocalyx. Mouse ZP2 is a sulphated zona pellucida glycoprotein with an apparent molecular mass of $120 \mathrm{kDa}$. ZP2 cDNA clones and genes have been cloned from various mammals, including humans, mice, cats, dogs, pigs and rabbits (Harris et al., 1994). After fertilization, the ZP2 protein is modified in the 'hardening reaction' to prevent polyspermy. This modification is caused by cortical granule exocytosis.

The most probable complementary sperm protein(s) for ZP2 mediated secondary binding is proacrosin/acrosin (TöpferPetersen and Henschen, 1987; Lo-Leggio et al., 1994). These enzymes are believed to be located at the inner acrosomal membrane, which displays sites that recognize the zona pellucida (Yanagimachi, 1981) and bind to ZP2 (Bleil et al., 1988; Mortillo and Wassarman, 1991). Other studies demonstrated that a fucoidan-binding protein is located on the inner acrosomal membrane and either on or in the equatorial segment of acrosome-reacted guinea-pig spermatozoa (Huang and Yanagimachi, 1984). In boar spermatozoa the fucoidanbinding compound was identified as acrosin (Töpfer-Petersen and Henschen, 1987). Tesarik et al. (1990) reported that in acrosome-reacted human spermatozoa, acrosin is found 
primarily in the equatorial segment but also in the inner acrosomal membrane. However, another polypeptide, $\mathrm{PH}-20$, a $64 \mathrm{kDa}$ protein with hyaluronidase activity, may be a primary or secondary zona receptor for guinea-pig and cynomologus macaque spermatozoa (Overstreet et al., 1995).

The different views and uncertainties about the chemical nature and site of the sperm counterpart(s) for the secondary ZP2 receptor make it difficult to understand the molecular mechanisms of mammalian sperm-oocyte interaction in detail. We have used an immunological approach to identify ZP2 epitopes that exhibit physiological relevance in sperm binding. One or more of those ZP2 domains might represent the counterparts for proteins (for example acrosin) localized in the sperm head. In the present study we demonstrate that antibodies against synthetic ZP2 peptides are useful tools for the assessment of defined linear ZP2 epitopes that reveal physiological function in the sperm-zona pellucida interaction process.

\section{Materials and Methods}

\section{Animals}

Female New Zealand white rabbits (approximately $4 \mathrm{~kg}$ ) were obtained from Charles River Wiga (Sulzfeld).

\section{Ethics of experimentation}

Human oocytes were obtained from patients participating in the in vitro fertilization-embryo transfer programme at the University of Bonn (Bonn, Germany). The specimens represented cells that were not included in the programme and which would normally have been discarded. The investigations have been approved by the local ethical committee. Immunization of rabbits and generation of antisera (Hinsch et al. 1994) were approved by the German authorities and performed in accordance with the German legal requirements.

\section{Materials}

Keyhole limpet haemocyanin (KLH), peroxidaseconjugated anti-rabbit IgG from goat, $o$-phenylenediamine dihydrochloride (OPD), 3,3'-diaminobenzidine (DAB), $\mathrm{H}_{2} \mathrm{O}_{2}$ Tween 20,0.1\% (v/v) polyvinylpyrrolidone (PVP), human serum albumin (HSA) and bovine serum albumin (BSA), Hepes buffer, Ham's F10 and haematoxylin were from Sigma (Deisenhofen). $\mathrm{MgCl}_{2}$ was purchased from Mallinkrodt Chemical works (St Louis, MO). Anti-rabbit IgG antibodies and peroxidase-antiperoxidase complex were purchased from DAKO (Hamburg). Micro-well immunomodules (Polysorp F 16) were from Nunc (Kamstrup). Dulbecco's phosphate-buffered saline (PBS) was from Seromed (Berlin).

\section{Methods}

Preparation of anti-ZP2 peptide antisera. The sequences of the synthetic peptides (Fig. 1) were deduced from cDNA clones coding for mammalian ZP2 (EMBL ID: HSZP2GP, AC number: M90366). The antigens represented ZP2 domains (Liang and Dean, 1993) that were homologous in human and mouse ZP2 (amino acid residues 541-555, ZP2-20 peptide) or present in the human but not in the mouse $Z \mathrm{P} 2$ amino acid sequence (amino acid residues 505-517, ZP2-26 peptide). Selection and synthesis of $\mathrm{ZP} 2$ peptides as well as crosslinking of peptides to keyhole limpet haemocyanin (KLH) were performed as described by Hinsch et al. (1997).

Enzyme-linked immunosorbant assay (ELISA) with anti-ZP2 peptide antisera. ELISA was performed with horseradish peroxidase-labelled anti-rabbit antibodies, $\mathrm{H}_{2} \mathrm{O}_{2}$ as substrate and $o$-phenylenediamine dihydrochloride as colour reagent. Micro-well immunomodules were coated with synthetic peptide ( $1 \mathrm{mg}$ in $100 \mathrm{ml}$ of distilled water). Coated wells were air-dried at $37^{\circ} \mathrm{C}$ for $12 \mathrm{~h}$. Subsequently, wells were washed with PBS supplemented with $0.05 \%$ (v/v) Tween 20. The coated wells were filled with antisera at appropriate dilutions in PBS ( $\mathrm{pH} 7.4$ ) supplemented with $1 \%(\mathrm{w} / \mathrm{v})$ BSA. After $1 \mathrm{~h}$ of incubation with the antiserum, wells were washed with PBS (pH 7.4) supplemented with $0.05 \%(\mathrm{v} / \mathrm{v})$ Tween 20. Subsequently, the wells were filled with peroxidase-conjugated anti-rabbit IgG (diluted 1:6000). After incubation for $45 \mathrm{~min}$, the wells were washed as described above. Finally, the wells were filled with $0.05 \mathrm{~mol}$ phosphate-citrate buffer $\mathrm{l}^{-1}(\mathrm{pH}$ 5.0) supplemented with $0.4 \mathrm{mg}^{\mathrm{OPD} \mathrm{m}} \mathrm{m}^{-1}$ and $0.001 \% \quad(\mathrm{v} / \mathrm{v}) \quad \mathrm{H}_{2} \mathrm{O}_{2}$. Colour development was complete after $20 \mathrm{~min}$. The absorbance was read at $492 \mathrm{~nm}$ using a Titertek Multiscan ${ }^{\mathrm{R}}$ ELISA reader (Titertek-Dynatech, Denkendorf,).

Competitive hemizona assay. The competitive hemizona assay (HZA) was carried out following the HZA described by Burkman et al. (1988) and used in previous studies (Oehninger et al., 1996). Five independent competitive hemizona assays were carried out using a total of 11 oocytes for antiserum AS ZP2-20 and 13 oocytes for AS ZP2-26. Human oocytes were collected from follicular aspirates. Adherent cumulus cells were removed mechanically using micropipettes, and oocytes were subsequently washed thoroughly. For storage, oocytes were placed in small plastic vials containing $0.5 \mathrm{ml}$ of $1.5 \mathrm{~mol} \mathrm{MgCl}_{2} \mathrm{l}^{-1}$ (Mallinkrodt Chemical works, St Louis, MO), $0.1 \%$ (v/v) PVP, and $40 \mathrm{mmol}$ Hepes buffer $\mathrm{I}^{-1}$. Denuded salt stored human oocytes were equally microbisected using an Axiovert 100 microscope equipped with a micromanipulator (Zeiss, Frankfurt). Hemizonae were separated from oocyte particles by micropipetting. Matching hemizonae were then incubated with test sera (anti-ZP2 antisera) or pre-immune sera (diluted 1:30) for $2 \mathrm{~h}$ at $37^{\circ} \mathrm{C}$ in $5 \% \mathrm{CO}_{2}$ in air.

Human spermatozoa were obtained from fertile men; the motile sperm fractions were obtained using a swim-up technique. Spermatozoa were capacitated in the presence of $0.3 \% \mathrm{HSA}(\mathrm{w} / \mathrm{v})$ for $1 \mathrm{~h}$ in an incubator at $37^{\circ} \mathrm{C}$ in $5 \% \mathrm{CO}_{2}$ in air. Thoroughly washed hemizonae were placed in a sperm suspension containing $0.5 \times 10^{6}$ motile spermatozoa $\mathrm{ml}^{-1}$ for $4 \mathrm{~h}$. After sperm-hemizona co-incubation, each hemizona was rinsed to remove loosely attached spermatozoa. Subsequently, the number of spermatozoa tightly bound to 
MACRQRGGSWSPSGWFNAGWSTYRSISLFFALVTSGNSIDVSQLVNP AFPGTVTCDEREITVEFPSSPGTKKWHASVVDPLGLDMPNCTYILDPE KLTLRATYDNCTRRVHGGHQMTIRVMNNSAALRHGAVMYQFFCPA MQVEETQGLSASTICQKDFMSFSLPRVFSGLADDSKGTKVQMGWSIE VGDGARAKTLTLPEAMKEGFSLLIDNHRMTFHVPFNATGVTHYVQG NSHLYMVSLKLTFISPGQKVIFSSQAICAPDPVTCNATHMTLTIPEFPG KLKSVSFENQNIDVSQLHDNGIDLEATNGMKLHFSKTLLKTKLSEKCL LHQFYLASLKLTFLLRPETVSMVIYPECLCESPVSIVTGELCTQDGFM DVEVYSYQTQPALDLGTLRVGNSSCQPVFEAQSQGLVRFHIPLNGCG TRYKFEDDKVVYENEIHALWTDFPPSKISRDSEFRMTVKCSYSRNDM AS ZP2-26 LLNINVESLTPPVASVKLGPFTLILQSYPDNSYOOPYGENEYPLVRFLR AS ZP2-20 QPIYMEVRVLNRDDPNIKLVLDDCWATSTMDPDSFPQWNVVVDGC AYDLDNYQTTFHPVGSSVTHPDHYQRFDMKAFAFVSEAHVLSSLVY FHCSALICNRLSPDSPLCSVTCPVSSRHRRATGATEAEKMTVSLPGPIL LLSDDSSFRGVGSSDLKASGSSGEKSRSETGEEVGSRGAMDTKGHKT AGDVGSKAVAAVAAFAGVVATLGFIYYLYEKRTVSNH

Fig. 1. Primary structure of the ZP2 amino acid sequence (Liang and Dean, 1993). The positions of amino acid sequences chosen for generation of anti-ZP2 synthetic peptide antisera AS ZP2-26 (bold and italics) and AS ZP2-20 (bold) are underlined. Amino acid sequences are given in the one-letter code.

the outer surface of each hemizona was counted. Finally, the hemizona index (HZI) was calculated $(\mathrm{HZI}=$ [number of sperm bound for test hemizona/number of sperm bound for control hemizona] $\times 100)($ Burkman et al., 1988).

\section{Immunochemistry with human hemizonae}

For evaluation of anti-ZP2 antibody binding to human zona pellucida proteins, immunochemical studies with human hemizonae were performed. The detection of hemizona-bound antibodies was essentially as described by Hinsch et al. (1994) and Oehninger et al. (1996). Briefly, human hemizonae were mounted on glass slides and air dried over night. Thereafter, test hemizonae were treated with antisera AS ZP2-20 (diluted 1:30) or AS ZP2-26 (diluted 1:30) for $1 \mathrm{~h}$; the matching control hemizonae were treated with pre-immune serum (diluted 1:30). Specific binding was visualized with anti-rabbit IgG antibodies (diluted 1:100), peroxidase-antiperoxidase complex (diluted 1:100) and DAB as colour reagent. After fixation in graded alcohols, slides were mounted with a coverslip. Immunostaining was evaluated and photographed using a Zeiss Axioskop microscope (Zeiss, Frankfurt).

\section{Statistical analysis}

Results are presented as means \pm SEM. Statistical analysis of the HZIs was carried out using the one sample $t$ test.

\section{Results}

Antisera were generated either against synthetic peptides corresponding to a conserved ZP2 amino acid sequence or against an epitope present in human ZP2 (Fig. 1). Synthetic peptides were selected on the basis of their probability of being antigenic as predicted by analysis of the primary structure (Krchnak et al., 1987). Specificity of antibodies and antibody titres were determined by ELISA. The results show that the anti-ZP2 antibodies reacted with the respective peptide used as antigen. Antiserum AS ZP2-26 detected the ZP2 human synthetic peptide, displaying a typical sigmoidal titration curve (Fig. 2a). Antiserum AS ZP2-20 clearly reacted with the ZP2 common synthetic peptide (Fig. 2b). However, reaction of antiserum AS ZP2-20 with its antigen was considerably lower than the reaction of antiserum AS ZP2-26 with its corresponding synthetic peptide. Antibodies from the respective pre-immune sera exhibited no binding to synthetic ZP2 peptides.

The competitive hemizona assay revealed that anti-ZP2 common antibodies affect human sperm-zona pellucida binding. Test hemizonae treated with AS ZP2-20 revealed an average of about 15 spermatozoa bound to the outer surface, whereas the corresponding control hemizonae yielded a mean value of 28 tightly bound cells (Table 1 ). The calculated hemizona index (about 52 on average) and the statistical analysis revealed a significant inhibition of sperm binding to the zona pellucida caused by AS ZP2-20 antibodies compared with control hemizonae treated with pre-immune serum $(P<0.0001)$. In contrast to the results with AS ZP2-20, preincubation of hemizonae with antiserum AS ZP2-26 did 
Table 1. Competitive hemizona assay with human gametes and anti-ZP2 peptide antisera

\begin{tabular}{lccccc}
\hline Antiserum & $\begin{array}{c}\text { Spermatozoa } \\
\text { (test HZ) }\end{array}$ & $\begin{array}{c}\text { Spermatozoa }^{b} \\
\text { (control HZ) }\end{array}$ & HZI & $\begin{array}{c}P \text { value } \\
(\text { HZI) }\end{array}$ & $n$ \\
\hline ASZP2-20 & 14.6 & 27.8 & 51.56 & $<0.0001$ & 11 \\
& $( \pm 3.0)$ & $( \pm 5.5)$ & $\begin{array}{c}( \pm 1.70) \\
100.82\end{array}$ & $>0.1$ & $\begin{array}{c}(22) \\
\text { ASZP2-26 }\end{array}$ \\
$\begin{array}{c}87.7 \\
( \pm 16.1)\end{array}$ & $\begin{array}{c}92.3 \\
( \pm 17.0)\end{array}$ & $( \pm 5.87)$ & & $(26)$ \\
\hline
\end{tabular}

"Code numbers of antisera used in the present study are given.

balues are mean numbers of human spermatozoa bound to outer human hemizona surface \pm SEM.

$n=$ Total number of human oocytes (number of hemizonae) used in five independent replicate assays; one test hemizona was incubated with anti-ZP2 peptide antiserum, the matching control - hemizona was treated with preimmune serum.
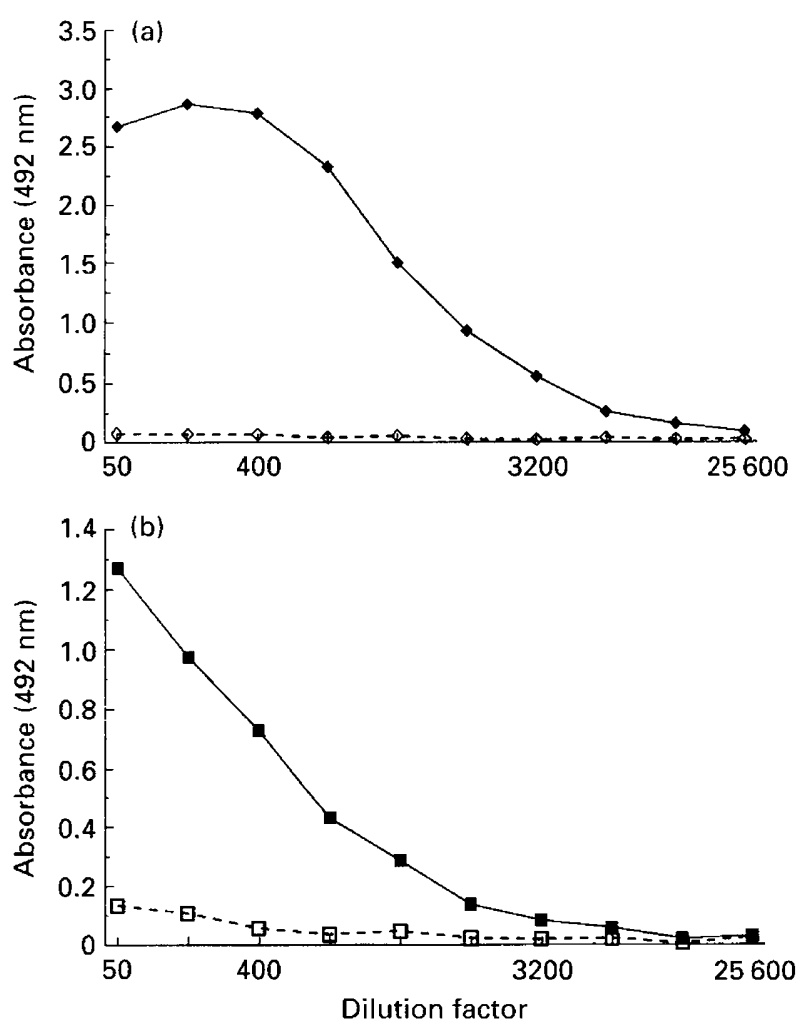

Fig. 2. Specificity of antisera raised against ZP2 peptides as determined by ELISA. The dilution factor of antisera is shown on the abscissa, the absorbance (492 nm) on the ordinate. One microgram of peptide antigen was used per well. (a) ZP2-26 peptide; $\bullet$ AS ZP2-26, $\diamond$ pre-immune serum 26; (b) ZP2-20 peptide; AS ZP2-20, $\square$ pre-immune serum 20.

not influence sperm-zona interaction. An average of 88 bound spermatozoa was counted when hemizonae incubated with AS ZP2-26 were used; the number of spermatozoa attached to control hemizonae was almost identical (about 92 spermatozoa on average). The hemizona index (about 101 on average) shows that anti-ZP2 human peptide antibodies do not influence sperm-zona binding. No significant change in sperm binding was calculated $(P=$ 0.89 ).
We also investigated whether anti-ZP2 antibodies bind to human hemizonae. A hemizona incubated with AS ZP2-20 exhibited staining throughout the zona pellucida (Fig. 3a). A brown ring was observed at the edge of the bisected zona pellucida; the amount of substrate deposition in the central part of the hemizona was slightly lower. The periphery of the hemizona revealed a ragged staining pattern towards the outer border, whereas the central portion of the hemizona exhibited a more homogeneous deposition of coloured substrate. Staining of the hemizona incubated with AS ZP2-26 appeared as an intense and clustered pattern of substrate deposition close to the edge of the hemizona (Fig. 3c). Hardly any staining was observed when matching hemizonae were treated with corresponding pre-immune sera (Fig. 3b,c).

\section{Discussion}

In this study, we have investigated whether antibodies against defined $\mathrm{ZP2}$ epitopes bind to $\mathrm{ZP}$ protein in human hemizonae and whether the respective $Z P$ domains detected by anti-ZP2 antibodies are of functional importance for sperm-zona pellucida interaction.

Antibodies against defined ZP2 epitopes were generated and characterized based on ZP2 CDNA sequences (Liang and Dean, 1993). The use of synthetic ZP2 peptides as immunogen provides several advantages over other ZP2 antigens. First, synthetic peptides can be synthesized in large quantities and with sufficient homogeneity. Second, no contaminating proteins will interfere with the outcome of the immunization and generate non-specific antibodies. Third, antisera against synthetic peptides can be used for the identification of ZP proteins that are only defined by molecular cloning. Finally, antisera against homologous ZP2 peptide sequences may allow the identification of unknown ZP2 variants, for example alternative splicing products. However, despite the advantages of synthetic peptide antigens, it must be remembered that antisera raised against synthetic ZP2 peptides can react only with the protein backbone of the ZP2 protein. Therefore, post-translational modifications (such as glycosylation) of zona pellucida proteins during zona pellucida assembly might prevent binding of antibodies to their antigen and lead to inconsistent results. 

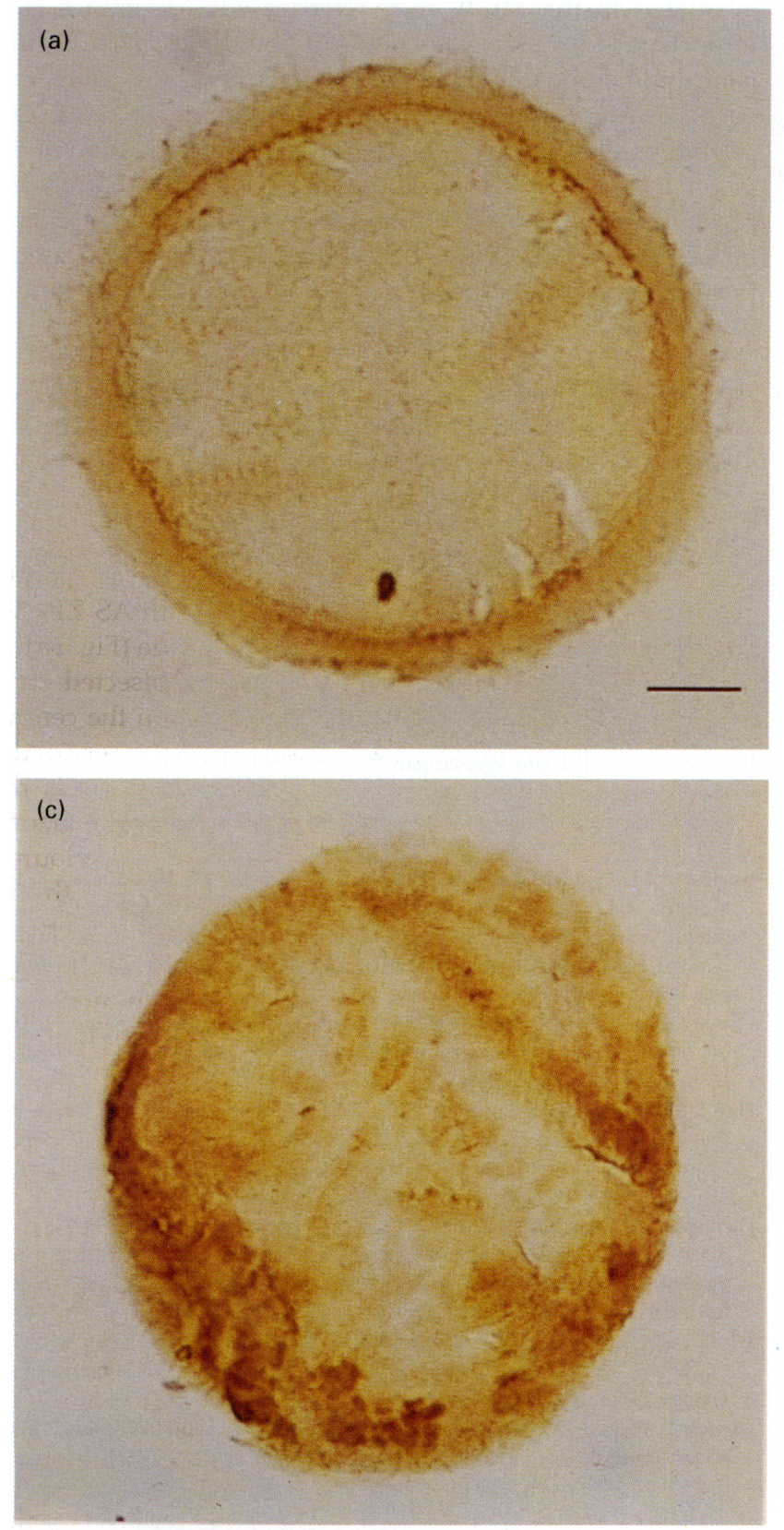

Fig. 3. Immunochemical localization of ZP2 protein in human hemizonae. Hemizonae were mounted on polylysine-coated glass slides. Air-dried hemizonae were incubated with antisera (1:30 dilution) AS ZP2-20 (a) and AS ZP2-26 (c). The incubation of pre-immune sera (1:30 dilution) was used as control (b,d). Binding of antibodies was evaluated using anti-rabbit IgG antibodies (diluted 1:100), peroxidase-antiperoxidase complex (diluted 1:100), and 3,3'-diaminobenzidine (DAB) as colour reagent. Scale bar represents $20 \mu \mathrm{m}$.

An ELISA developed for the detection of antibodies against synthetic ZP2 peptides was used and anti-ZP2 antisera were shown to react strongly with the synthetic ZP2 peptides that were used as antigens. The antisera did not crossreact with other synthetic peptides; thus, the specificity of antibody reaction could be demonstrated. However, it is essential to demonstrate that the antisera also detected ZP2 protein. It has been shown that antisera AS ZP2-20 and AS ZP2-26 both reacted with $Z \mathrm{P} 2$ protein in immunoblots and that the antisera also specifically detected zona pellucida protein in sections of the human ovary (Hinsch et al., in press). (d)
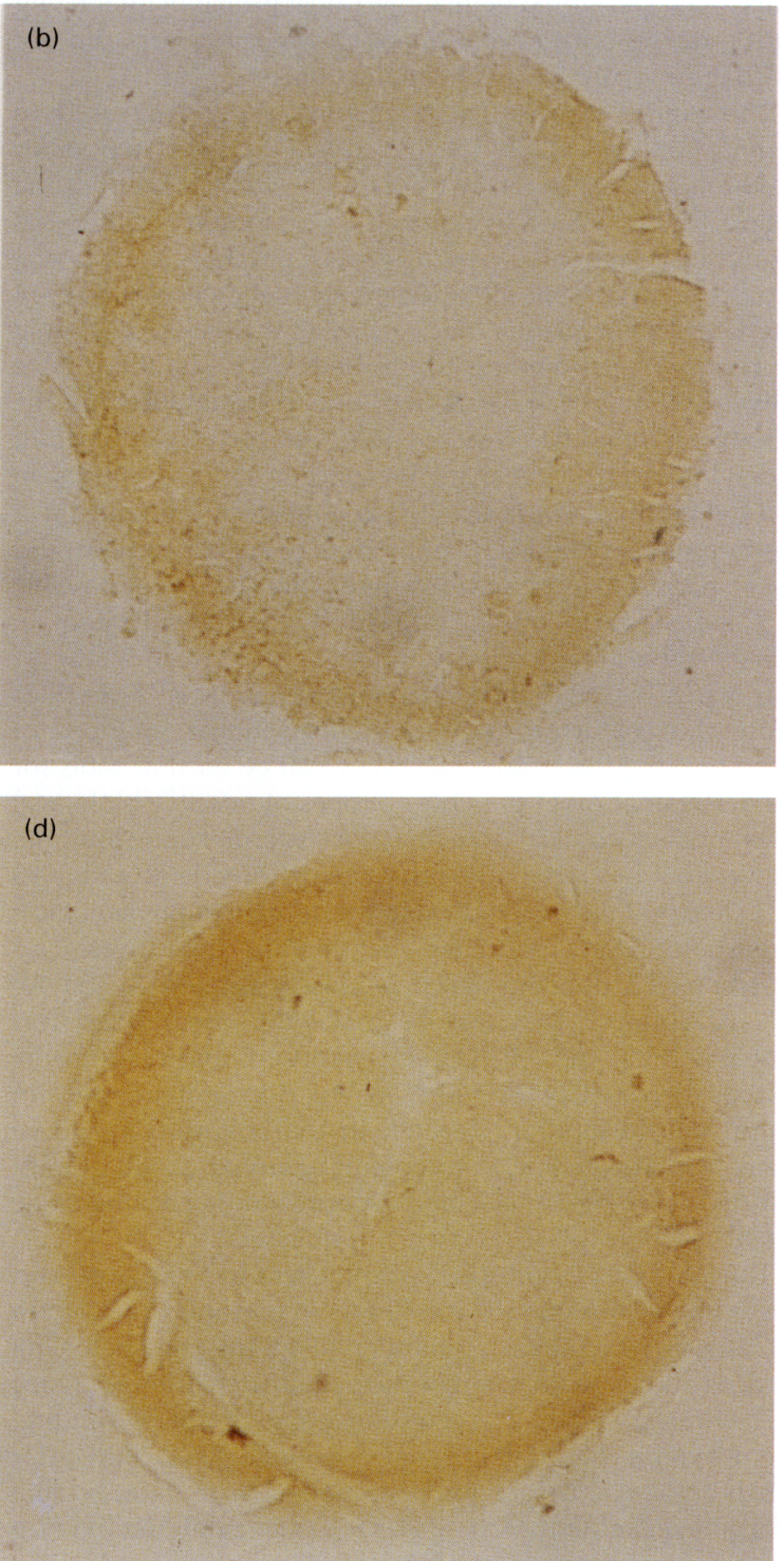
rehydrated salt stored hemizonae (most probably interacting with a defined linear ZP2 domain), this antiserum did not block sperm-zona pellucida interaction.

The human competitive hemizona assay was used to demonstrate that highly specific anti-ZP2 peptide antibodies and human gametes can be used for the study of sperm-zona pellucida interaction. Anti-ZP2 common antibodies significantly inhibited sperm-zona binding, whereas the antiserum against the ZP2-human synthetic peptide did not interfere. The hemizona index revealed that AS ZP2-20 only decreased sperm binding to the hemizonae by about $50 \%$. This result might indicate that the concentration or the affinity of antibodies was not sufficient for a total block of sperm binding. However, higher concentrations of antiserum and pre-immune serum resulted in non-specific interaction of pre-immune antibodies with the zona pellucida and thus did not result in a lower hemizona index (not shown). A possible explanation for this finding is that more than one ZP2 domain is responsible for secondary binding.

It is possible that antisera against synthetic ZP2 peptides allow the characterization of defined linear epitopes of discrete ZP2 protein antigens. They can be used as tools for the determination of possible epitopes of possible biological relevance, such as domains for sperm-zona binding. However, it has to be noted that the epitope detected by AS ZP2-20 might not be identical to the domain of physiological importance. Steric hindrance of antibodies could influence a different ZP2 domain which is closely located to the AS ZP2-20 epitope. Two reasons make this assumption less probable. First, AS ZP2-26 detects an epitope close to the epitope detected by AS ZP2-20 but does not interfere in sperm-oocyte binding. Second, in the bovine competitive hemizona assay, $\mathrm{F}(\mathrm{ab})_{2}$ fragments derived from affinity purified AS ZP2-20 IgG block sperm binding to the same extent as whole IgG (E. Hinsch, unpublished).

The AS ZP2-20 epitope is also present in the mouse and pig amino acid sequence and differs in one amino acid from cat, dog, and rabbit ZP2. Inhibition of sperm-zona pellucida binding indicates that antibodies against this homologous ZP2 sequence block a species-independent sperm binding site. Koyoma et al. (1991) generated monoclonal antibodies (MAb-5H4) against porcine zona pellucida protein. In vitro assays revealed that $\mathrm{MAb}-5 \mathrm{H} 4$ antibodies inhibited binding of human spermatozoa to the homologous zona pellucida. Epitope mapping of $\mathrm{MAb}-5 \mathrm{H} 4$ showed that the antibodies detect an amino acid sequence close to the N-terminal of the porcine zona pellucida glycoprotein pZP4; in contrast, antisera AS ZP2-20 and AS ZP2-26 detect epitopes near the $\mathrm{C}$-terminal region. The $\mathrm{pZP} 4$ domain recognized by $\mathrm{MAb}$ $5 \mathrm{H} 4$ displays sequence identity to human ZP2 (8 out of 10 amino acids) but differs from mouse ZP2 in 4 out of 10 amino acids. Antibodies directed against a synthetic pZP4 peptide that corresponds to the MAb-5H4 epitope recognized zona pellucida from pigs, humans and rabbits but not from mice (Hasegawa et al., 1995). The antisera inhibited porcine fertilization in vitro but had no effect on sperm-zona binding immediately after insemination. These results and our data suggest that antibodies against two different ZP2 epitopes inhibit secondary binding of spermatozoa.

In conclusion, the conserved peptide sequence that was evaluated in this study may reflect a ZP2 domain that is important for secondary sperm binding. The results contribute to the understanding of the important events that occur during sperm-zona pellucida interaction. Anti-ZP2 peptide antibodies may be useful for the investigation of the physiology of sperm-oocyte interaction. The evaluation of a physiological role of ZP2 domains detected by antisera used in this study in species other than humans as well as the properties of the respective synthetic peptides are under investigation.

The authors wish to thank S. Gröger for excellent technical assistance. Thanks are also due to M. Montag (Bonn) for helpful discussions and to U. Dieckmann (Bonn) for technical assistance and help with the handling of human oocytes. This project was supported by the Deutsche Forschungsgemeinschaft (Hi 610/1-2). This publication includes parts of the thesis of W. Hägele.

\section{References}

Bleil JD, Greve JM and Wassarman PM (1988) Identification of a secondary sperm receptor in the mouse egg zona pellucida: role in maintenance of binding of acrosome-reacted sperm to eggs Developmental Biology 128 376-385

Burkman LJ, Coddington CC, Franken DR, Kruger TF, Rosenwaks $Z$ and Hodgen GD (1988) The hemizona assay (HZA): development of a diagnostic test for the binding of human spermatozoa to the human hemizona pellucida to predict fertilization potential Fertility and Sterility 49 $688-697$

Greve JM and Wassarman PM (1985) Mouse egg extracellular coat is a matrix of interconnected filaments possessing a structural repeat Joumal of Molecular Biology 181 253-264

Harris JD, Hibler DW, Fontenot GK, Hsu KT, Yurewicz EC and Sacco AG (1994) Cloning and characterization of zona pellucida genes and cDNAs from a variety of mammalian species: The ZPA, ZPB and ZPC gene families DNA Sequence - The fournal of Sequencing and Mapping 4 361-393

Hasegawa A, Yamasaki N, Inoue M, Koyama K and Isojima S (1995) Analysis of an epitope sequence recognized by a monoclonal antibody $\mathrm{MAb}-5 \mathrm{H} 4$ against a porcine zona pellucida glycoprotein (pZP4) that blocks fertilization Journal of Reproduction and Fertility 105 295-302

Hinsch E, Hägele W, Schill W-B and Hinsch KD (1997) The zona pellucida "receptors". In The Fate of the Male Germ Cell pp 314-328 Eds R Ivell and AF Holstein. Plenum Press, New York

Hinsch E, Hägele W, van der Veen $H$, Oehninger S, Schill WB and Hinsch KD Immunological identification of zona pellucida 2 (ZP2) protein in human oocytes Andrologia (in press)

Hinsch KD, Hinsch E, Meinecke B, Töpfer-Petersen E, Pfisterer S and Schill WB (1994) Identification of mouse ZP3 protein in mammalian oocytes with antisera against synthetic ZP3 peptides Biology of Reproduction 51 193-204

Huang TTF and Yanagimachi R (1984) Fucoidin inhibits attachment of guinea pig spermatozoa to the zona pellucida through binding to the inner acrosomal membrane and equatorial domains Experimental Cell Research 153 363-373

Koyama K, Hasegawa A, Yamasaki N, Inoue $\mathbf{M}$ and Isojima S (1991) Blocking of human sperm-zona interaction by monoclonal antibodies to a glycoprotein family (ZP4) of porcine zona pellucida Biology of Reproduction $45727-735$

Krchnak V, Mach O and Maly A (1987) Computer prediction of potential immunogenic determinants from protein amino acid sequences Analytical Biochemistry 165 200-207

Liang LF and Dean J (1993) Conservation of mammalian secondary sperm receptor genes enables the promoter of the human gene to function in mouse oocytes Developmental Biology 156 399-408

Lo-Leggio L, Williams RM and Jones R (1994) Some effects of zona pellucida glycoproteins and sulphated polymers on the autoactivation of boar sperm proacrosin and activity of beta-acrosin Journal of Reproduction and Fertility $100177-185$ 
Mortillo S and Wassarman PM (1991) Differential binding of gold-labelled zona pellucida glycoproteins $\mathrm{mZP} 2$ and $\mathrm{mZP} 3$ to mouse sperm membrane compartments Development 113 141-149

Oehninger S, Hinsch E, Kolm P, Schill WB, Hodgen GD and Hinsch KD (1996) Use of specific zona pellucida protein 3 (ZP3) antiserum as a clinical marker for human zona pellucida integrity and function Fertility and Sterility 65 139-145

Overstreet JW, Lin J, Judin AI, Meyers SA, Primakoff P, Myles DG, Katz DF and Vandevoort CA (1995) Location of the $\mathrm{pH}-20$ protein on acrosomeintact and acrosome-reacted spermatozoa of cynomolgus macaques Biology of Reproduction 52 105-114

Shabanowitz RB and O'Rand MG (1988) Molecular changes in the human zona pellucida associated with fertilization and human sperm receptor Annals of the New York Academy of Sciences $551621-632$

Tesarik J, Drahorad J, Testart J and Mendoza C (1990) Acrosin activation follows its surface exposure and precedes membrane fusion in human sperm acrosome reaction Development 110 391-400

Töpfer-Petersen E and Henschen A (1987) Acrosin shows zona and fucose binding, novel properties for a serine proteinase FEBS Letters $22638-42$

Vazquez MH, Phillips DM and Wassarman PM (1989) Interaction of mouse sperm with purified sperm receptors covalently linked to silica beads Journal of Cell Science 92 713-722

Wassarman PM (1990) Profile of a mammalian sperm receptor Development $1081-17$

Yanagimachi R (1981) Mechanisms of fertilization in mammals. In Fertilization and Embryonic Development In Vitro pp 81-187 Eds L Mastroianni and JD Biggers. Plenum Press, New York

Yanagimachi R (1994) Mammalian fertilization. In The Physiology of Reproduction 2nd Edn pp 189-317 Eds E Knobil and JD Neill. Raven Press Ltd, New York 